\title{
Correspondence
}

Contents: Psychiatric morbidity and compulsory admission/The safety and efficacy of clozapine?/ Alzheimer's disease and Lewy body dementia/ Anorexic siblings/Neuroleptic malignant syndrome and carbamazepine.

\section{Psychiatric morbidity and compulsory admission}

SIR: One interesting but undiscussed finding of Thomas et al (BJP, July 1993, 163, 91-99) is of the low rate of admissions from ethnic minorities for non-psychotic disorders (see Table below). Further research on this topic would undoubtedly be valuable, although may be difficult to achieve in an area which grant-giving bodies are likely to perceive as unproblematic (Littlewood \& Lipsedge, 1989).

Table to show rates of first admission and readmission for different ethnic groups

\begin{tabular}{|c|c|c|c|}
\hline & Europeans & Asians & $\begin{array}{c}\text { Afro- } \\
\text { Carribbeans }\end{array}$ \\
\hline $\begin{array}{l}\text { Non-psychotic } \\
\text { admissions } \\
\text { Non-psychotic }\end{array}$ & 192 & 15 & 8 \\
\hline readmissions & 351 & 10 & 13 \\
\hline Populations at risk & 48624 & 4289 & 4679 \\
\hline $\begin{array}{l}\text { Rate per } 1000 \text { non- } \\
\text { psychotic } \\
\text { admissions } \\
\text { Rate per } 1000 \text { non- } \\
\text { psychotic } \\
\text { readmissions }\end{array}$ & 3.95 & 3.44 & 1.71 \\
\hline
\end{tabular}

LiTTLEWOOD, R. \& LIPSEDGE, M. (1989) Aliens and Alienists: Ethnic Minorities and Psychiatry (2nd edn), p. 257. London: Unwin Hyman.

Charing Cross and Westminster Medical School

6th Floor, Laboratory Block

Charing Cross Hospital

London W6 8RE

AUTHORS' REPLY: Dr Ineichen's observation that the rate of admission for non-psychotic disorders among ethnic minority groups in Central Manchester (BJP, July $1993,163,91-99$ ) is reduced in comparison to Europeans is correct. The table he has produced is of collapsed data (abstracted from Table 3 of our paper, $\mathrm{p}$ 95), for all age groups by ethnic group. The $95 \%$ confidence intervals (Diem \& Lentner, 1970) for each rate per year per 100000 population for first admissions are: European 98.7 (84.3-112.6); Asian 87.4 (48.9-144.2); and Afro-Caribbean 42.7 (18.4-84.1)*. For readmissions the $95 \%$ confidence intervals are: European 180.5 (161.6-199.9); Asian 58.3 (28.0-107.2)*; and Afro-Caribbean 69.5 (37.0-118.9)* (*indicates that the $95 \%$ confidence intervals are non-overlapping.)

Compared with Europeans, the rates of first admission for Afro-Caribbeans and readmission for Afro-Caribbeans and Asians are significantly reduced. Some caution must be exercised when interpreting these results because the number of subjects within each ethnic grouping was small and there were difficulties in estimating the various population denominators.

If these findings are not due to methodological error then it suggests that, in comparison with Europeans, ethnic minorities are either less prone to minor psychiatric morbidity or underuse or access psychiatric services differently (Brewin, 1980). We agree with Dr Ineichen that further research is necessary to establish the level of psychiatric morbidity among ethnic minorities and also that services may have to adapt to meet the needs of these different groups.
BrewIN, C. (1980) Explaining the lower rates of psychiatric treatment among Asian immigrants in the United Kingdom: a preliminary study. Social Psychiatry, 15, 17-19.
DiEM, K. \& LeNTNER, C. (1970) Scientific tables. In Documenta Geigy (7th edn) (eds K. Diem \& C. Lentner). Basle: Geigy.

CHRISTOPHER S. THOMAS

University Hospital of South Manchester

Manchester M20 8LR

Hope Hospital, Manchester

KIT StONE

Manchester Royal Infirmary, Manchester

MADELINE OSBORN

Ysbyty Gwynedd, Bangor

Phil Thomas

\section{The safety and eficacy of clozapine?}

SIR: Since the Clozapine Study Group's paper showed that clozapine is both unsafe and ineffective, why is their report (BJP, August 1993, 163, 150-154) 